\title{
Investigation of in vitro Antioxidant and Anti-inflammatory Activities of Selected Siddha Polyherbal Formulations
}

\author{
Perumal Rajalakshmi*, Vellingiri Vadivel, Pemaiah Brindha \\ Centre for Advanced Research in Indian System of Medicine, SASTRA University, Thanjavur, Tamilnadu, INDIA.
}

\begin{abstract}
Objective: This study deals with the antioxidant and anti-inflammatory activities of selected Siddha polyherbal formulations such as Amukkara choornam, Thirikadugu choornam, Eladi choornam and Thiripala choornam. Amukkara choornam consist of seven herbals (withania, ginger, black pepper, long pepper, mesua, cardamom and clove). Thirikadugu choornam has three herbal ingredients ginger, black pepper and long pepper. Eladi choornam has seven raw drugs like cardamom, ginger, arrow root, yew leaves, Mesua, black pepper and clove. Thiripala choornam comprises of three dry fruits amla, chebulla and bellerica. Methods: Even though all these medicines have been used as analgesic for joint pain in Siddha system of medicine, their antioxidant and anti-inflammatory activities were not yet proved scientifically. In the present work, we have evaluated the antioxidant and anti-inflammatory properties of aqueous extract of the above-mentioned herbal formulations. Results: Among the investigated formulations, Thiripala choornam has six folds higher level of total phenolic content (1248 mf GAE/100 g) when compared to other formulations (190.42 - $199.78 \mathrm{mg} \mathrm{GAE} / 100 \mathrm{~g}$ ). Similarly, Thiripala choornam exhibited promising antioxidant activity in terms of radical scavenging potential against DPPH (IC-50: $156 \mathrm{mg} / \mathrm{L}$ ), superoxide (IC-50: $2303 \mathrm{mg} / \mathrm{L}$ ), hydrogen peroxide (IC-50: 294 $\mathrm{mg} / \mathrm{L}$ ) and hydroxyl radical (IC-50: $587 \mathrm{mg} / \mathrm{L}$ ) and anti-inflammatory activity (IC-50: 24 $\mathrm{mg} / \mathrm{L})$. Conclusion: Among the investigated samples, Thiripala choornam was found to exhibit high antioxidant and anti-inflammatory potential and thus could be used as more effective analgesic formulation.
\end{abstract}

Key words: Aqueous extract, Polyphenols, Antioxidant, Anti-inflammatory, Amukkara choornam, Thirikadugu choornam, Eladi choornam, Thiripala choornam.

\section{INTRODUCTION}

Siddha system of medicine uses so many poly herbal formulations for the joint pain. The usage of Non-steroidal anti-inflammatory drugs (NSAID) in the treatment of painful musculo-skeletal conditions often results in adverse effects such as gastric irritation, renal damage etc. By the way, poly herbal medicines are not dangerous, efficient, time-tested and devoid of severe side-effects. Siddha medicine has many such herbal formulations for the treatment of joint pain (arthritis). ${ }^{1}$ In this study we have selected four medicines, which are used for joint pain such as Amukkara choornam
(AMK), Thirikadugu choornam (TKC), Eladi choornam (ELC) and Thiripala choornam (TPC). ${ }^{2}$ These Choornams are powdered form of a single drug or a mixture more drugs, which retain their medicinal value for three months. ${ }^{3}$

$A M K$ therapeutically used as an analgesic, nervine tonic, gastric ulcer, hiccups, peripheral neuritis, and ashthma, ${ }^{4}$ rheumatic diseases, sexual insufficiency and insomnia ${ }^{2}$. It consists of several herbal ingredients like root of Withania somnifera (L.) Dunal, rhizome of Zingiber officinale Roscoe (ginger), dry seed of Piper nigrum L. (black pepper), dry
Submission Date: 30-08-2017; Revision Date: 14-09-2017; Accepted Date: 25-10-2017

DOI: 10.5530/ijper.51.4s.108 Correspondence: Dr. Rajalakshmi $P$, Centre for Advanced Research in Indian System of Medicine, SASTRA University, Thanjavur, Tamilnadu, INDIA. E-mail: rajalakshmi@carism. sastra.edu

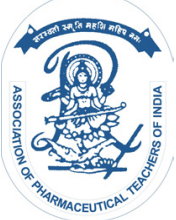

www.ijper.org 
seeds of Piper longum L. (long pepper), flower bud of Mesua ferrea L. (Indian rose chestnut), dry fruit of Elletaria cardamomum L. (cardamom) and flower bud of Sysygium aromaticum L. (clove). All these ingredients are powdered and mixed in the ratio of clove - one part, Mesua -2 parts, cardamom - 4 parts, long pepper -8 parts, block pepper - 16 parts, dry ginger -32 parts, withania root - 64 parts and sugar - 128 parts..$^{4,5,6,7}$

TKC medicinally used for respiratory problems like body pain, asthma, tuberculosis, pneumonia, sinusitis fever and digestive disorders like indigestion, loss of appetite, flatulence, constipation, nausia and vomiting, skin diseases and antitote for all poisons. ${ }^{2}$ Previously research work proved that TKC has good anthelmintic activity (Devi et al., 2011). It has three ingredients such as rhizome of Zingiber officinale Roscoe, seeds of Piper nigrum $\mathrm{L}$ and Piper longum $\mathrm{L}$, which are made into fine powder and mixed in equal quantity. ${ }^{5,6}$

All the ingredients of ELC such as cardamom (Elettaria cardamomum L.), ginger (Zingiber officinale Roscoe), arrow root (Maranta arundinacea L.), yew leaves (Abies webbiana (D. Don) Spach), Indian rose chestnut (Mesua ferrea L.), pepper (Piper nigrum L) and clove (Sysygium aromaticum (L.) Merrill and Perry) are separately powdered and sieved through a fine mesh. ${ }^{5}$ then the required quantities of cardamom (64 parts), ginger (32 parts), arrow root (16 parts), yew leaves (8 parts), Indian rose chestnut (4 parts), pepper (2 parts), clove (1 part) and sugar (128 parts) are taken and thoroughly mixed (Kuppusamy and Uthamarayan, 1998). Therapeutically it is used for indigestion, gastritis, vatha diseases, pitha diseases, skin diseases, skin ulcer, and tuberculosis and over bleeding. ${ }^{5}$ this medicines standardization work was done by Thankamma et al, $1998 .{ }^{?}$

TPC consists of three dry fruits like Terminalia chebula Retr. Terminalia bellirica (Gaertn.) Roxb and Phyllanthus emblica L. All the fruits are crushed, removed the seeds and the peel was collected and made into fine powder and mixed in equal quantity. ${ }^{10}$ It act as a astringent and therapeutically it is used for gastric ulcer, mouth ulcer, skin disease, cough, anaemia, leucorrhea, constipation, piles, wounds, gum bleeding, liver toxic symptoms and also used for analgesic, ascites and hyper tension. ${ }^{2,11}$ Previously research study proved that TPC has anticancer activity in both cellular and in vivo models. ${ }^{12}$ Another review article mentioned that TPC has effective antioxidant, antibacterial, anti-viral, and used to treat cataract and AIDS. ${ }^{13}$

Even though these medicines have several therapeutic uses and few research studies have been conducted on their therapeutic potential, the antioxidant and anti-inflammatory activities of aqueous extract of the selected herbal formulations are not yet revealed. This research paper revealed with the in vitro antioxidant and anti-inflammatory properties of herbal medicines documented in Siddha classic text.

\section{MATERIALS AND METHODS}

\section{Preparation of the drug}

Raw ingredients of $A M K, T K C, E L C$, and TPC were procured from local herbal market, Thanjavur, Tamilnadu, India and identified and authenticated in the NABL accredited lab of CARISM, SASTRA University. All the ingredients were powdered (particle size $1 \mathrm{~mm}$ ) individually using a lab mill and then mixed according formulation given in Siddha formulary of India, 1992..$^{5}$

\section{Extract preparation}

Twenty five $\mathrm{g}$ of each formulation were taken separately in a conical flask and extracted with $250 \mathrm{ml}$ of distilled water and kept for $24 \mathrm{~h}$. Then the aqueous extract was filtered through filter paper. After filtration, the filtrates were dried in vacuo (freeze drier - Christ Alpha 2 - $4 \mathrm{LD}$ Plus, Germany) and re-dissolved in water at $5000 \mathrm{mg} / \mathrm{L}$ ratio and used for further experiments.

\section{Total phenol content}

The total phenolic content of extract was estimated according to the method of Singleton et al.,1999. ${ }^{14}$ Sample $(100 \mu \mathrm{l})$ was taken with $250 \mu \mathrm{l}$ of Folin's-Ciocalteu reagent and $1000 \mu \mathrm{l}$ of $5 \%$ of $\mathrm{Na}_{2} \mathrm{CO}_{3}$ were added and incubated for $30 \mathrm{~min}$ in dark place. Then the absorbance was measured at $720 \mathrm{~nm}$. A calibration curve was prepared using standard gallic acid $(16-100 \mathrm{mg} / \mathrm{L}$; $y=0.0094 x-0.0585 ; \mathrm{R} 2=0.9939)$ and used to express the results as gallic acid equivalents (mg GAE / $100 \mathrm{~g}$ sample).

\section{DPPH radical scavenging activity}

The DPPH radical scavenging assay was used to analyze the antioxidant property of aqueous extracts of the samples by following Sanchez-Moreno et al., 1998 method..$^{15}$ Different concentrations (5000, 2500, 1250, $625,312,156,78,39,19,9.7 \mathrm{mg} / \mathrm{L})$ of extract $(100 \mu \mathrm{l})$ were added to $0.9 \mathrm{ml}$ of methanolic solution of DPPH $(2.5 \mathrm{mg} / 100 \mathrm{ml})$ and the reactants were incubated at room temperature for $30 \mathrm{~min}$ in dark. Solvent (distilled water) was used instead of extract in control. After $30 \mathrm{~min}$, the absorbance was measured at $515 \mathrm{~nm}$ using a spectrophotometer and the radical scavenging activity of the extract was calculated and expressed on percentage basis.

\section{Superoxide radical scavenging activity}

The capacity of extract to scavenge the superoxide anion radical was measured according to the method 
described by Zhishen et al., 1999. ${ }^{16}$ The reaction mixture was prepared using $3 \times 10-6 \mathrm{M}$ riboflavin, $1 \times 10-2 \mathrm{M}$ methionine, $1 \times 10-4 \mathrm{M}$ nitroblue tetrozolium chloride and $0.1 \mathrm{mM}$ EDTA in phosphate buffered saline ( $\mathrm{pH}$ 7.4). For the analysis, $3.0 \mathrm{ml}$ of the reaction mixture was taken with $100 \mu \mathrm{l}$ of extract in closed tubes and illuminated for $40 \mathrm{~min}$ under fluorescent lamp (18 W). The absorbance was then read at $560 \mathrm{~nm}$ against the un-illuminated reaction mixture. Results are expressed as superoxide radical scavenging activity on percentage basis.

\section{Hydrogen peroxide scavenging activity}

The effect of extract on hydrogen peroxide was analyzed according to the method proposed by Ruch et al.. ${ }^{17}$ The extract (100 microliter) was mixed with $5 \mathrm{ml}$ of $45 \mathrm{mM}$ hydrogen peroxide solution in $0.1 \mathrm{M}$ phosphate buffer $(\mathrm{pH}$ 7.4). The reaction mixture was vortexed and incubated for $30 \mathrm{~min}$ at room temperature and then the absorbency was measured at $230 \mathrm{~nm}$. The extract with phosphate buffer is used as a blank and the level of hydrogen peroxide remaining in the solution was calculated using a calibration curve. The hydrogen peroxide inhibition effect of extract was calculated and expressed on percentage basis.

\section{Hydroxyl radical scavenging activity}

The hydroxyl radical quenching activity of extracts was evaluated according to the method of Hagerman et.al., 1998. ${ }^{18}$ The reaction mixture consists of $10 \mathrm{mM}$ phosphate buffer ( $\mathrm{pH} 7.4$ ), $2.8 \mathrm{mM}$ Deoxyribose, $2.8 \mathrm{mM}$ $\mathrm{H} 2 \mathrm{O} 2,0.025 \mathrm{mM} \mathrm{FeCl}, 0.1 \mathrm{mM}$ EDTA and $0.1 \mathrm{mM}$ ascorbic acid in a total volume of $3 \mathrm{ml}$. With the reaction mixture, 100 microliter of extract was added and incubated at $37^{\circ} \mathrm{C}$ for $15 \mathrm{~min}$. Then the reaction was terminated by the addition of $1 \mathrm{ml}$ of $2.5 \%$ ice-cold TCA and 1\% TBA. The reactants were mixed well and heated at $90 \mathrm{C}$ for $15 \mathrm{~min}$ in a water bath and cooled to room temperature. The chromogen was extracted with 1-butanol and absorbency was measured at $530 \mathrm{~nm}$. Based on absorbency value, the hydroxyl radical scavenging activity of extracts was calculated and expressed on percentage basis.

\section{Anti-inflammatory activity}

Anti-inflammatory activity of aqueous extracts of samples was evaluated using RBC membrane stabilization assay. ${ }^{19}$ Human blood $(2 \mathrm{ml})$ was drawn from volunteer in a heparinized tube and centrifuged at $2000 \mathrm{rpm}$ for 10 min. The pellet (RBC cells) was washed twice with PBS $(9 \mathrm{ml})$ and finally the pellet was re-suspended in $10 \mathrm{ml}$ of PBS. Different concentrations (5000, 2500, 1250, 625, 312, 156, 78, 39, 19, $9.7 \mathrm{mg} / \mathrm{L}$ ) of extract $(500 \mu \mathrm{l})$ were added to $1 \mathrm{PBS}, 1 \mathrm{ml}$ of $3 \% \mathrm{H}_{2} \mathrm{O}_{2}$ and incubated for $30 \mathrm{~min}$. In normal control, $1 \mathrm{ml}$ PBS was added instead of extract and in negative control only $\mathrm{H}_{2} \mathrm{O}_{2}$ was added. After incubation, the contents were centrifuged at $2000 \mathrm{rpm}$ for $10 \mathrm{~min}$ and the supernatant was used to measure the absorbance at $520 \mathrm{~nm}$. Based on the absorbance, the percentage of RBC membrane damage and inhibition of membrane damage were calculated.

\section{RESULTS AND DISCUSSION}

Total phenol content

Plant phenols are the natural antioxidant compounds, have wide range of physiological properties such as anti-allergenic, anti-artherogenic, anti-inflammatory, anti-microbial, antioxidant, anti-thrombotic, cardioprotective and vasodilatory effects. ${ }^{20}$ the total phenolic content of selected polyherbal formulations was given in Figure 1. Among the studies formulations, TPC possesses the higher level of phenols when compared to other formulations of the study.

\section{Antioxidant activity}

Reactive Oxygen Species (ROS) are produced in both unstressed and stressed cells. Oxidation reactions generate free radicals that can start multiple chain reactions, which eventually cause damage or death to the cell. Free radicals cause many human diseases like cancer Alzheimer's disease, cardiac reperfusion abnormalities, kidney disease, fibrosis, etc. The free radicals formed in our body are combated by antioxidants that safely interact with free radicals and terminate the chain reaction

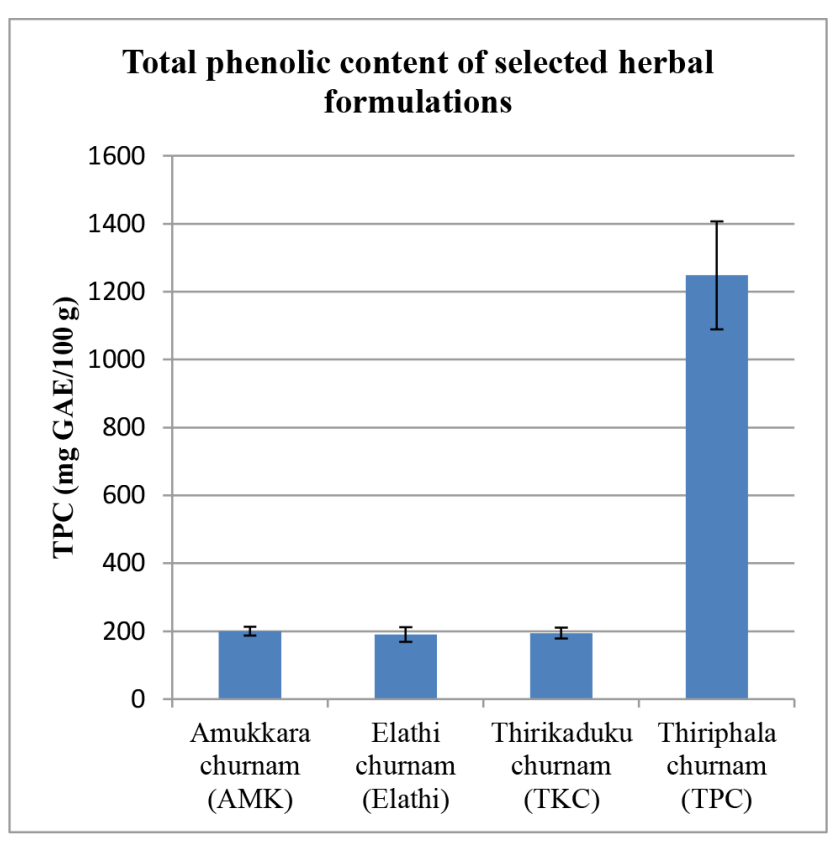

Figure 1: Total phenolic concentration of poly herbal formulations. 
before vital molecules are damaged. ${ }^{21}$ Such oxidative process are dangerous for all living cells and oxidative stress is playing a significant part of many human diseases that can occur due to a lack of suitable nutrition and exercise, air pollution, smoking, artificial foods and more leading to lethal diseases such as cancer.

Plants have well developed defense system against ROS, involving both limiting the formation of ROS as well as instituting its removal. Under unstressed conditions the formation and removal of $\mathrm{O}_{2}$ are in balance. However, the defense system, when presented with increased ROS formation under stress condition, can be overwhelmed. Plants respond to a rise in ROS that the defense system is unable to remove with increased enzymatic or no enzymatic antioxidant process, but the mechanisms underlying these processes is not well understood. ${ }^{22}$ Antioxidant compounds can eliminate these free-radical intermediates by being oxidized themselves and inhibit other oxidation reactions, thus preventing the harmful chain reactions. Therefore, it is very important to include antioxidants in our diets. In pharmaceutical industries antioxidants are added to enhance the stability of therapeutic agents that are susceptible to chemical degradation by oxidation. Unfortunately, recent research indicating that the synthetic antioxidants could have carcinogenic effects on human cells, thus fueling an intensive search for new, natural and efficient antioxidants.

\section{DPPH radical scavenging activity}

The DPPH radical scavenging activity of different Siddha poly herbal medicines were illustrated in the Figure 2. The evaluation of the antioxidant power by DPPH radical scavenging activity has been widely in use for different plant extracts. DPPH (2,2-Diphenyl1-picrylhydrazyl) is a stable radical, methanolic solution of which has dark purple colour with maximum absorption at $515 \mathrm{~nm}$. Among the investigated herbal formulations, Triphala churnam exhibited highest DPPH radical scavenging power, which is followed by Trikaduku churnam, Amukkara churnam and Eladi churnam. All the herbal formulations exhibited dose-dependant antioxidant activity and the IC-50 value of 156, 1171, 2286 and $5067 \mu \mathrm{g} / \mathrm{ml}$ were recorded by Triphala churnam, Trikaduku churnam, Amukkara churnam and Eladi churnam.

\section{Superoxide radical scavenging activity}

The superoxide radical scavenging activity of aquas extracts of selected poly herbal powders are exposed in Figure 3. Superoxide is produced by the addition of a single electron to oxygen, and several mechanisms exist by which superoxide can be produced in vivo. Several molecules, including adrenaline, flavine nucleotides, thiol

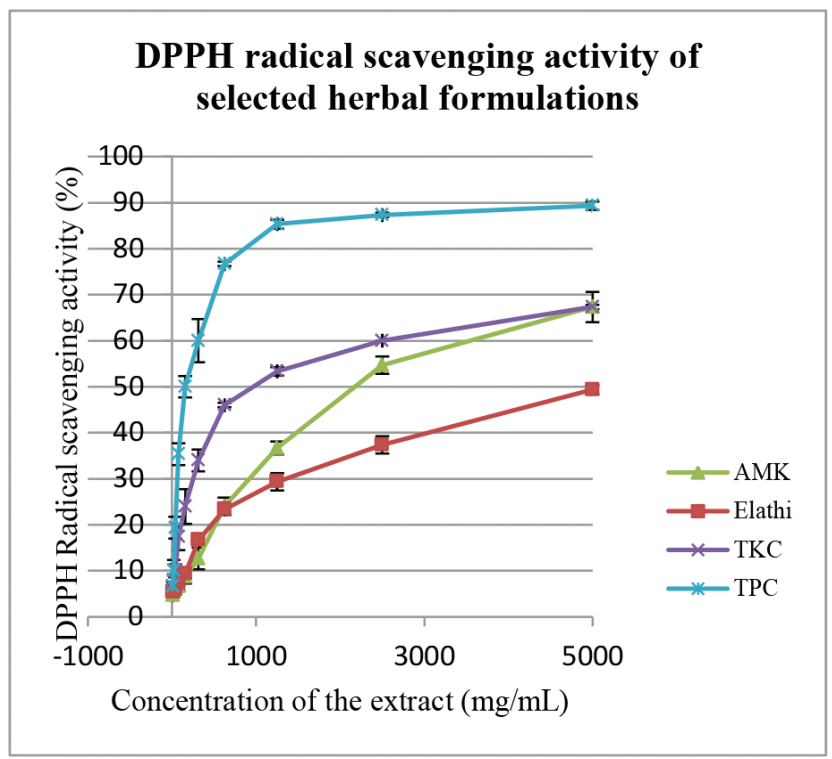

Figure 2: DPPH radical scavenging activity of selected herbal formulations.

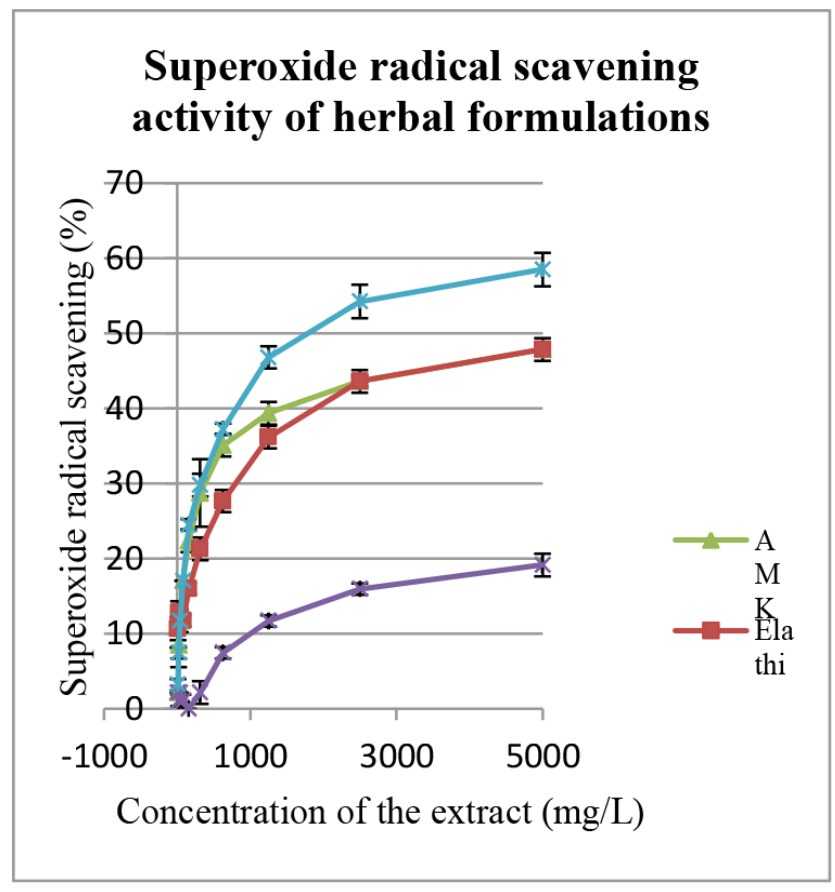

Figure 3: Superoxide radical scavenging activity of herbal formulations.

compounds, and glucose, can oxidize in the presence of oxygen to produce superoxide, and these reactions are greatly accelerated by the presence of transition metals such as iron or copper. The electron transport chain in the inner mitochondrial membrane performs the reduction of oxygen to water. During this process free radical intermediates are generated, which are generally tightly bound to the components of the transport chain. However, there is a constant leak of a few electrons into 


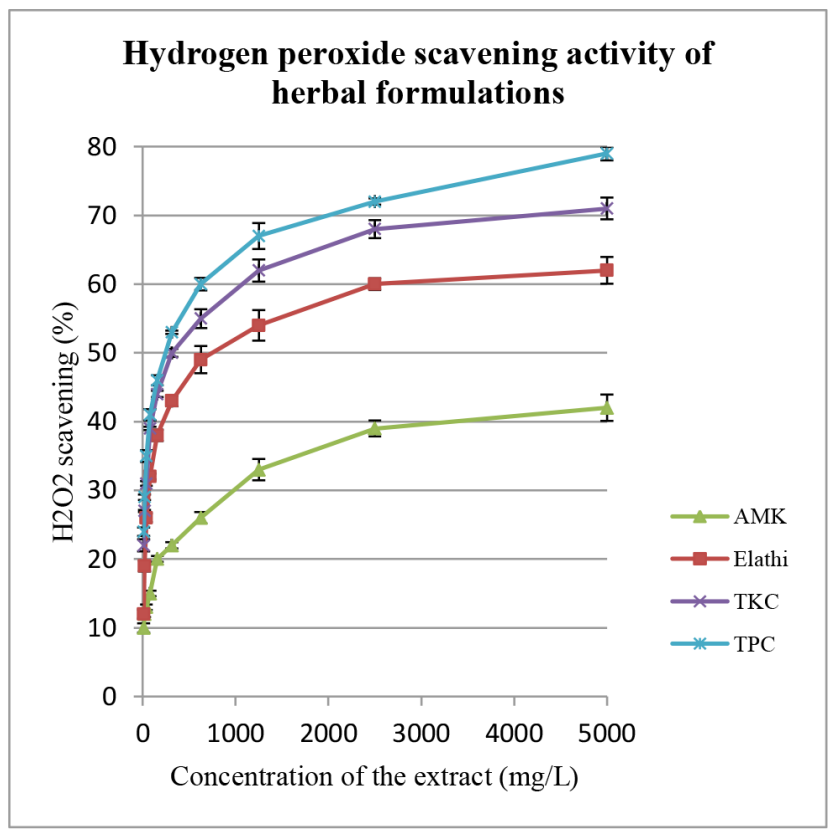

Figure 4: Hydrogen peroxide inhibition activity herbal formulations.

the mitochondrial matrix and it results in the formation of superoxide. ${ }^{24}$ The superoxide radical scavenging activity of Triphala churnam is found to be very high $\left(\mathrm{IC}_{50} 2303 \mu \mathrm{g} / \mathrm{ml}\right)$, when compared to Amukeara churnam $\left(\mathrm{IC}_{50} 5222 \mu \mathrm{g} / \mathrm{ml}\right.$ ), Eladi churnam $\left(\mathrm{IC}_{50} 5222\right.$ $\mu \mathrm{g} / \mathrm{ml})$ and Trikaduku churnam $\left(\mathrm{IC}_{50} 13054 \mu \mathrm{g} / \mathrm{ml}\right)$.

\section{Hydroxyl radical scavenging activity}

The hydroxyl radical scavenging activity aqueous extracts of four Siddha poly herbal medicines were presented in the Figure 4. Any biological system generating superoxide will also produce hydrogen peroxide as a result of a spontaneous dismutation reaction. In addition, several enzymatic reactions, including those catalysed by glycolate oxidase and $\mathrm{D}$-amino acid oxidase, might produce hydrogen peroxide directly. Hydrogen peroxide is not a free radical itself, but is usually included under the general heading of reactive oxygen species. ${ }^{24}$ Among the investigated herbal formulations, Triphala churnam and Trikaduku churnam have exhibited strong inhibition effect against hydrogen peroxide with the IC-50 value of 294 and $312 \mu \mathrm{g} / \mathrm{ml}$, respectively, which are followed by Eladi churnam (IC-50 $1157 \mu \mathrm{g} / \mathrm{ml}$ ) and Amukekara churnam showed poor inhibition (IC-50 value $5952 \mu \mathrm{g} / \mathrm{ml})$.

The hydroxyl radical scavenging activity of Siddha medicines were presented in the Figure 5. The hydroxyl radical $(\mathrm{OH})$, or a closely related species, is probably the final mediator of most free radical induced tissue damage. All the reactive oxygen species described above

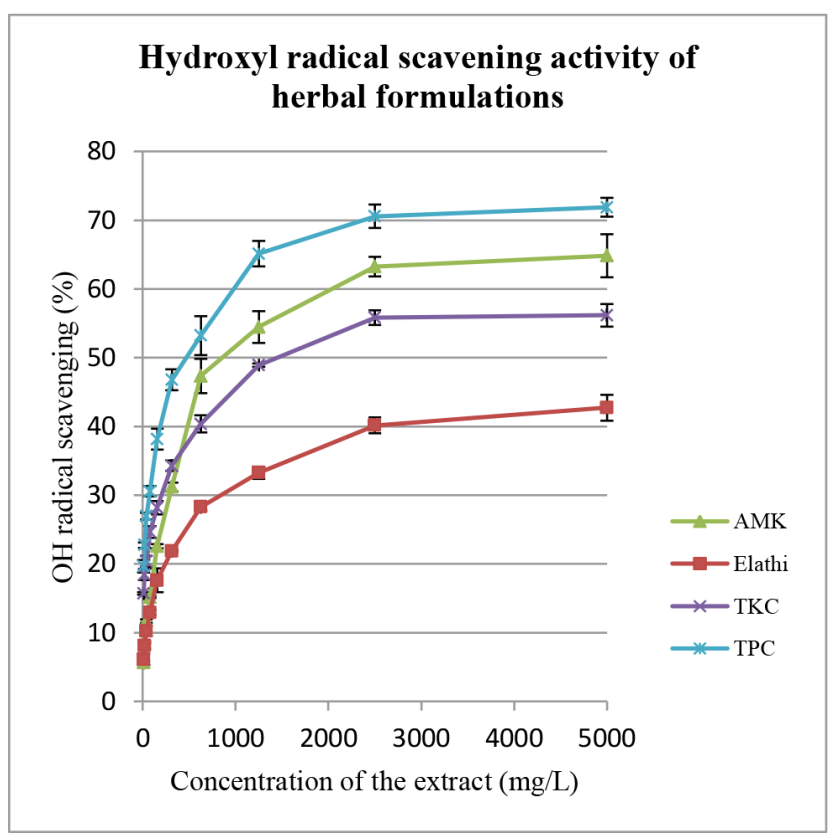

Figure 5: Hydroxyl radical inhibition.

exert most of their pathological effects by giving rise to hydroxyl radical formation. The reason for this is that the hydroxyl radical reacts, with extremely high rate constants, with almost every type of molecule found in living cells including sugars, amino acids, lipids, and nucleotides. Although hydroxyl radical formation can occur in several ways, by far the most important mechanism in vivo is likely to be the transition metal catalysed decomposition of superoxide and hydrogen peroxide. ${ }^{24}$ In agreement to other in vitro assays (DPPH, Superoxide and Hydrogen peroxide inhibition), Triphala churnam recorded prominent hydroxyl radical scavenging power (IC-50 $587 \mu \mathrm{g} / \mathrm{ml}$ ) among the investigated samples. But, in contrast the Amukekara churnam is also found to be effective against hydroxyl radicals (IC-50 $1147 \mu \mathrm{g} / \mathrm{ml}$ ) whereas Trikaduku churnam (IC-50 2238) and Eladi churnam (IC-50 $5847 \mu \mathrm{g} / \mathrm{ml}$ ) were found to be weak antioxidants.

\section{Anti-inflammatory activity}

Cyclooxygenase is the important enzymes in the production of prostaglandins, prostacyclins and thromboxanes which are involved in inflammation, pain and platelet aggregation. Steroidal and non-steroidal anti-inflammatory drugs are currently the most commonly used drugs in the treatment of acute inflammatory disorders. Its adverse effect damaged to the renal and gastric systems. These drugs obstruct cyclooxygenase enzyme activity results to prevent prostaglandin production. These type of SAID and NSAID drugs chronic usage gives 


\begin{tabular}{|c|c|c|}
\hline \multicolumn{3}{|c|}{ Table 1: Anti-inflammatory activity. } \\
\hline S. No & Herbal formulation & $\begin{array}{c}\text { Anti-inflammatory activity } \\
\text { (IC-50 values, } \boldsymbol{\mu g} / \mathbf{m l} \text { ) }\end{array}$ \\
\hline 1. & Amukkara choornam & 35.19 \\
\hline 2. & Thirikadugu choornam & 83.93 \\
\hline 3. & Eladi choornam & 58.96 \\
\hline 4. & Thiripala choornam & 24.00 \\
\hline
\end{tabular}

harmfulness to human biological system such as liver, gastrointestinal tract, cardiovascular, renal failure. ${ }^{25}$

Along with the presently studies herbal formulations of Amukeara churnam (35.19), Thirikadugu choornam (83.93), Eladi choornam (58.96)and Thiripala choornam (24.00) were displayed that Thirikadugu choornam has higher level of anti-inflammatory activities in terms of RBC membrane stabilization. Table 1

\section{CONCLUSION}

In the present work, we have evaluated the total phenolic content, antioxidant and anti-inflammatory activities of four common herbal formulations such as Amukkara churnam, Eladi churnam, Trikaduku churnam and Triphala churnam. Even though herbal ingredients of the selected formulations are different, all are useful in treating arthritis (Joint pain). A good relationship was noticed between high content of phenolic compounds and higher level antioxidant activity of Triphala cburnam in terms of radical scavenging activity against DPPH, superoxide, hydrogen peroxide and hydroxyl radicals and also anti-inflammatory property through RBC membrane stabilization. Such remarkable antioxidant and anti-inflammatory properties of Triphala churnam might be due to its herbal ingredients like Embelica officinalis, Terminalia chebula and Terminalia bellerica, which all are known as rich source of polyphenols. Among the investigated herbal formulations, Triphala churnam could be effective against oxidative-stress related diseases including arthritis.

\section{ACKNOWLEDGEMENT}

Authors are thankful to the Hon'ble Vice Chancellor of SASTRA University for his constant encouragement and support to carry out this research work.

\section{CONFLICT OF INTEREST}

There is no conflict of interest.

\section{ABBREVIATIONS USED}

NSAID: Non-steroidal anti-inflammatory Drugs; AMK: Amukkara choornam; TKC: Thirikadugu choornam; ELC: Eladi choornam; TPC: Thiripala choornam; AIDS: Acquired immune deficiency syndrome; NABL: National Accreditation Board for Testing and Calibration Laboratories; GAE: Gallic acid equivalents; DPPH: 2,2-Diphenyl-1-picrylhydrazyl; $\mathbf{H}_{2} \mathbf{O}_{2}$ : Hydrogen peroxide; $\mathrm{FeCl}_{3}$ : Ferric chloride; EDTA: Ethylenediamine tetra acetic acid; TCA: Trichloroacetic acid; TBA: Thio barbituric acid; RBC: Red blood cells; PBS: Phosphate buffered saline; ROS: Reactive oxygen species; IC-50: Inhibitory concentration-50; OH': Hydroxyl radical.

\section{REFERENCES}

1. M Sathya, C Aswini, A Shifana Raheema, S Merish and Thomas M Walter. Invitro Screening of a Poly Herbal Siddha Formula for Its Anti-Inflammatory Properties.Research Journal of Pharmaceutical, Biological and Chemical Sciences. 2014;5(3):992-8

2. Anonymous. Formulary of Siddha medicines, published by the Indian Medical Practitioners' Cooperative Pharmacy and Stores Ltd., Adyar, Madras.

3. Thyagaraja Mudaliyar, GunapadamThaathu Jeeva vaguppu, IIIrd Edn, Indian Medical Association. 1981, 1989.

4. K.N.KuppusamyandK.S.Uthamarayan ,Siddha Vaithiya Thirattu, $1^{\text {st }}$ edition, reprint 2009. Department of Indian Medicine and Homeopathy, Chennai.

5. Anonymous., The Siddha Formulary of India .Part I. Ministry of Health and Family Welfare, Government of India, New Delhi.1992.

6. K.M. Nadkarani, A.K. Nadkarani,. Indian Materia Medica, Vol:1, Publisher: Popular Prakash, Mumbai, India. 1954.

7. Kartik Ch Patra, Jayaram kumar K, Suresh P. Standardization of a polyherbal Siddha formulation, Amukkara choornam. Indian Journal of Traditional Knowledge. 2009;8(3):449-52.

8. M.S.Shree devi and B.Sampath kumar. Anthelmintic activity of thirikadugu chooranam and its ingredients. Asian Journal of Pharmaceutical and Clinical Research. 2011;4 (3):58-60.

9. Thankamma A, L.G. Radhika and C. Soudamini, Standardisation of Eladichoornam. Ancient Science of Life. 1998;18(1): $35-40$

10. Narayanaswami V. Pharmacopoeia of Hospital of Indian Medicine. Published by Tamilnadu Siddha Medical Board, Chennai, 1995

11. Murugesa mudalier K.S, Gunapadam Mooligai Vaguppu. Second edition, Second reprint. Tamilnadu Siddha Medical Council, Chennai, 2008.

12. Shi Y, Ravi P, Sanjay S, Srivastava K. Triphala inhibits both in vito and in vivo Xeno graft growth of pancreatic tumor cells by inducing apoptosis, BMC Cancer. 2008; 8: 294.

13. Neethu S Kumar, Arun S Nair, Anju M Nair, Megha Murali .Pharmacological and therapeutic effects of triphala - A literature review. Journal of Pharmacognosy and Phytochemistry 2016; 5(3): 23-7.

14. Singleton VL, Orthofer R, Lamuela-Raventos RM. Analysis of total phenols and other oxidation substrates and antioxidants by means of Folin-Ciocalteu reagent. Methods in Enzymology, 1999. 299: 152-178.

15. Sanchez-Moreno C, Larrauri JA, Saura-Calixto F. Free radical scavenging capacity and inhibition of lipid oxidation of wines, grape juices and related polyphenolic constituents. Food Research International 1999; 32: 407-412.

16. Zhishen J, Mengcheng $T$ and Jianming $W$. The determination of flavonoid contents in mulberry and their scavenging effects on superoxide radicals. Food Chemistry. 1999; 64: 555- 9

17. Ruch RJ, Cheng SJ, Klaunig JE. Prevention of cytotoxicity and inhibition of intracellular communication by antioxidant catechins isolated from Chinese green tea. Carcinogenesis. 1989; 10: 1003-8. 
18. Hagerman, A.E., Riedl, K.M., Jones, G.A., Sovik, K.N., Ritchard, N.T., and P.W. Hartzfeld. Highmolecular weight plant polyphenolics (tannins) as biological antioxidants. Journal of Agricultural and Food Chemistry. 1998; 46: 1887- 92.

19. Sakat S, Juvekar AR, Gambhire MN. In vitro antioxidant and anti-inflammatory activity of methanol extract of Oxalis corniculata Linn. International Journal of Pharmacy and Pharmaceutical Sciences 2010; 2(1): 146-55.

20. Nagendran Balasundram, Kalyana Sundram, Samir Samman. Phenolic compounds in plants and agri-industrial by-products: Antioxidant activity, occurrence, and potential uses. Food Chemistry 99 (2006) 191-203.

21. Abheri Das Sarma, Anisur Rahaman Mallick and A. K. Ghosh. Free Radicals and Their Role in Different Clinical Conditions: An Overview. International Journal of Pharma Sciences and Research (IJPSR) Vol.1(3), 2010, 185-192
Biology, 2002; 53(372): 1331-41 Ruth grene Alscher, Naval Erturk, Lenwood S. Heath. Role of superoxide dismutases (SODs) in controlling oxidatine stress in plants. Journal of Experimental.

23. Yevgenia Shebis, David Iluz, Yael Kinel-Tahan, Zvy Dubinsky, Yaron Yehoshua. Natural Antioxidants: Function and Sources. Food and Nutrition Sciences. 2013; 4:643-9.

24. Young, I. S., Woodside, J. V. Antioxidants in health and disease. Journal of Clinical Pathology. 2001;54:176-86.

25. Sunita Verma. Medicinal plants with anti-inflammatory activity. The Journal of Phytopharmacology 2016; 5(4): 157-9.

\section{PICTORIAL ABSTRACT}

Amukkara choornam (AMK)

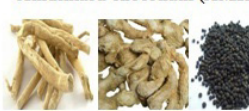

Thirikadugu choornam (TKC)

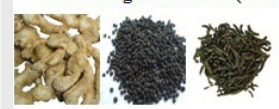

Eladi choornam (ELC)

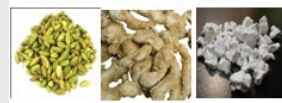

Thiripala choornam (TPC)
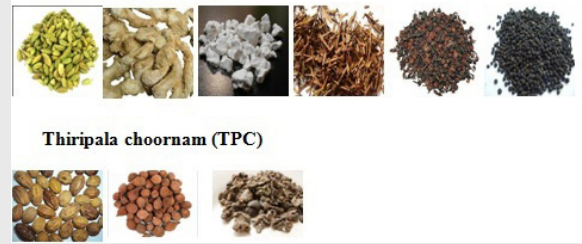

13 ises
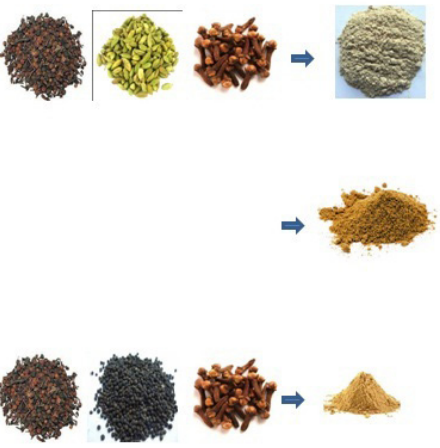

- Among the investigated herbal formulations, Triphala churnam is found to be effective antioxidant and anti-inflammatory drug.

\section{About Authors}

Mrs. Perumal Rajalakshmi: Is working as Assistant Professor at the Centre for Advanced Research in Indian System of Medicine, SASTRA University, Thanjavur, India.

Dr. Vellingiri Vadivel: Is working as Research Scientist at the Centre for Advanced Research in Indian System of Medicine, SASTRA University, Thanjavur, India.

Dr. Pemaiah Brindha: Is working as Associate Dean at the Centre for Advanced Research in Indian System of Medicine, SASTRA University, Thanjavur, India.

Cite this article: Rajalakshmi P, Vadivel V, Brindha P. Investigation of in vitro Antioxidant and Anti-inflammatory Activities of Selected Siddha Polyherbal Formulations. Indian J of Pharmaceutical Education and Research. 2017;51(4S):S747-S53. 